\title{
Les courants d'air et d'eau dans les puits verticaux
}

\section{Air and water currents in vertical shafts}

\author{
par Mrchele VIPARELLI \\ PROFESSEUR D'HYDRAULIQUE, UNIVERSITÉ DE NAPLES
}

\begin{abstract}
Lorsque les pressions ḋ l'entrée et à la sortie d'un puits sont égales, l'eau s'écoule, en chute libre, le long des parois. Il se constitue, aux faibles débits, un "noyau» central d'air, entouré par un anneau extérieur d'eau en écoulement vers le bas; aux débits élevés, le «noyau 》'air se décompose en grandes bulles, ou en poches d'air. Dans les deux cas, la vitesse de l'air s'approche de celle de l'eau, $\dot{a}$ mesure que la longueur du puits augmente. Lorsque la pression à la sortie du puits dépasse celle d̀ l'entrée, un ressaut hydraulique occupe généralement la partie inférieure du puits. Pour un ressaut complètement formé, le débit d'entraînement de l'air dépend, d'une part, de la hauteur de chute libre de l'eall d l'amont et, d'autre part, de l'écoulement à l'aval du ressaut. Pour un ressaut incomplet, le débit d'air est fonction des vitesses de l'eau qui n'ont pas encore été amorties par l'agitation présente dans le ressaut.

L'auteur indique quelques valeurs du rapport entre les débits d'air et d'eau, en fonction, $\dot{a}$ la fois, de la différence entre les pressions $\dot{a}$ l'entrée et à la sortie, et de la hauteur de chute libre de l'eau.
\end{abstract}

Dans le cadre des recherches ayant pour objet d'étudier les dispositifs pouvant chasser l'air contenu dans un courant d'eau, une installation expérimentale a été réalisée au Laboratoire d'Hydraulique de Naples, dans laquelle un courant d'air et d'eau était créé à l'intérieur d'un puits vertical alimenté par l'intermédiaire d'une spirale [1].

L'objet de ces expériences étant la séparation de l'air et de l'eau (1), les données expérimentales sur l'écoulement de l'air à l'intérieur du puits ont seulement été recueillies afin de fournir une vue d'ensemble plus complète. Néanmoins, au dernier stade des essais, ces données ont paru être d'un intérêt général, surtout com-

(1) Les résultats relatifs à l'objet principal de ces recherches ont été examinés dans un mémoire antérieur de l'auteur [1].

\begin{abstract}
When the shaft inlet and outlet pressures are equal, the water falls freely along the walls; at low discharges, a central air core forms, surrounded by an annular flow of water; at high discharges, the air core breals up into large bubbles or air pockets. In both cases, the air velocity tends more and more towards the water velocity as the length of the shaft increases.

When the pressure at the outlet exceeds that at the inlet, a hydraulic jump usually forms in the lowest portion of the shaft. If the jump is complete, the air entrainment rate depends both on the free-falling distance of the water above and the flow downstream. If the jump is incomplete, the air flow depends on the water velocities before they are damped out by the very agitated conditions in the jump.
\end{abstract}

Air-to-water discharge ratios for some of the cases described are given in terms of pressure difference between the shaft inlet and ontlet, and of the free-falling distance of the water.

In order to investigate some devices whereby air might be expelled from a stream of water, an experimental installation was built in the Naples Hydraulics Laboratory, which basically consisted of a vertical pipe (referred to as the shaft in this paper) in which a stream of air and water was generated, the entry of the shaft being in the form of a spiral [1].

Since the aim of the experiments was the separation of air from water (1), data were only collected on the air flow in the shaft in order to complete the picture. However, at the final stage, they appeared to be of general interest, especially if compared with and added to others published during the last few years $[2,3,4]$.

(1) Results referring to the chief aim of the research were the subject of a previous paper by the Author [1]. 
parées et prises avec d'autres résultats publiés au cours de ces dernières années $[2,3,4$,$] .$

Il a été possible de déduire, à partir de l'ensemble de ces données, quelques lois régissant le phénomène de l'entraînement d'air à l'intérieur d'un puits vertical. Le présent rapport donne les conclusions les plus intéressantes tirées de ces recherches.

\section{Installation expérimentale du Laboratoire de Naples}

Afin de pouvoir créer un courant mixte d'air et d'eau plusieurs fois de suite dans les mêmes conditions, l'installation a été réalisée sous forme d'un petit canal avec, à son extrémité aval, un dispositif d'alimentation en spirale débitant dans un puits vertical (fig. 1). Ce puits pouvait avoir deux longueurs différentes $\left(\mathrm{A}_{1}\right.$ et $\mathrm{A}_{2}$ ) : l'une, telle
From all these data it was possible to deduce some laws for the phenomenon of air entrainment in a vertical shaft. This paper will give the more interesting conclusions.

\section{The Naples laboratory installation}

In order to obtain a mixed current of air and water under repetitive conditions, a small channel ending with a spiral entrance discharged water into a shaft (fig. 1). This shaft was designed to have two different lengths (positions $A_{1}$ and $A_{2}$ ), so that it could end either at the top or at an intermediate section of a vertical cylinder, the top part of which contained air, and the bottom part water. A deflector fitted at the end

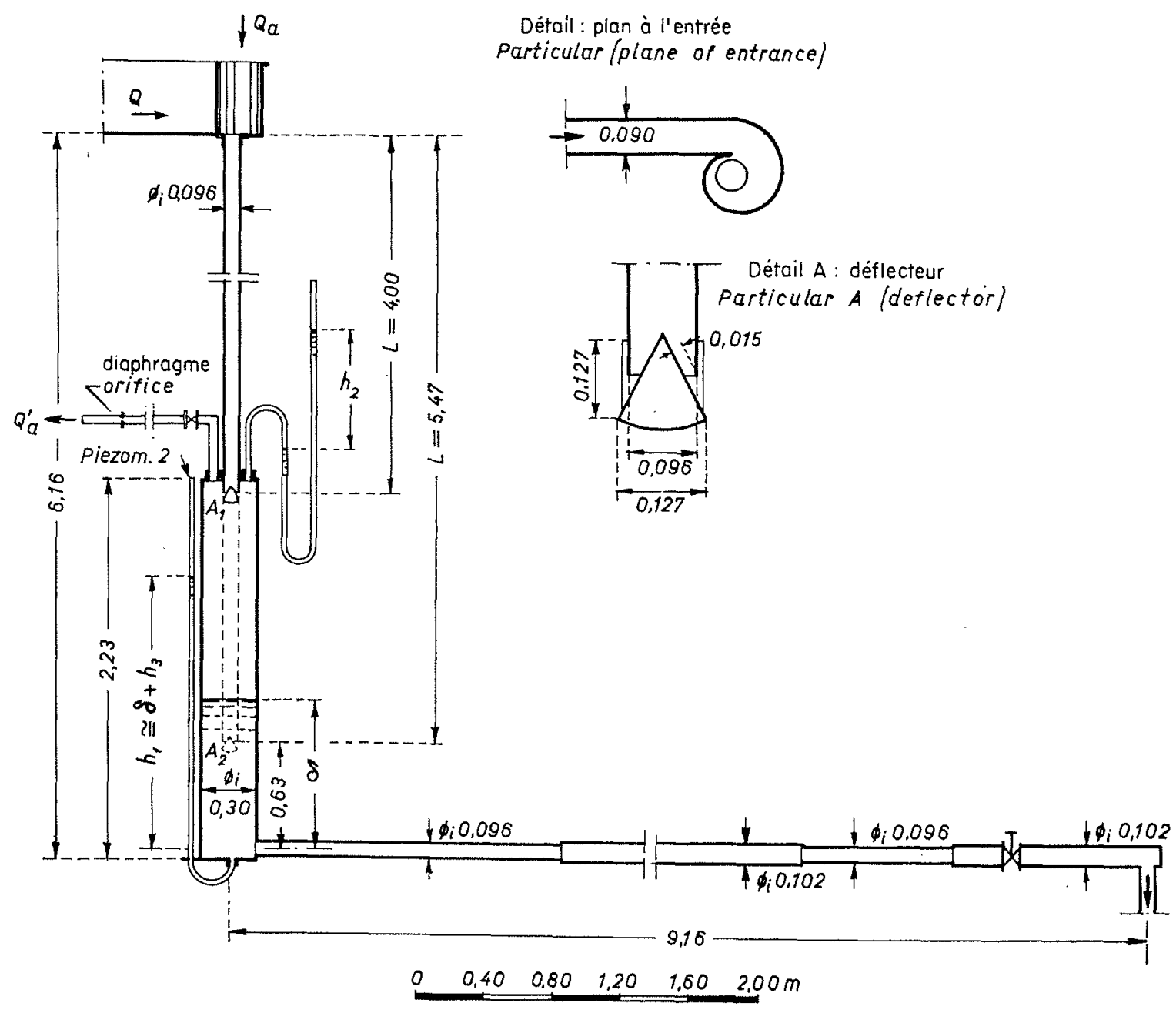

FIG. 1

L'installation expérimentale utilisée à Naples.

The Naples experimental installation, 
qu'il se terminait au bout d'un cylindre vertical, et la deuxième, telle qu'il aboutissait à une partie intermédiaire de ce cylindre, dont la partie supérieure était remplie d'air, et la partie inférieure remplie d'eau.

Un déflecteur était adapté à l'extrémité inférieure du puits vertical, afin de dévier le jet vers les parois du cylindre et de favoriser la séparation de l'air. L'évacuation de l'eau à partir du fond du cylindre se faisait par l'intermédiaire d'un tuyau horizontal, alors que l'évacuation de l'air s'effectuait en haut du cylindre, par un robinet et un diaphragme. Le réglage de la hauteur d'eau à l'intérieur du cylindre s'effectuait au moyen d'une vanne à l'extrémité du tuyau horizontal, et celui de la pression de l'air audessus de l'eau par le robinet prévu, à cette fin, dans la conduite d'air; ces dispositions permettaient d'obtenir, dans la partie supérieure du cylindre, une pression $p_{2}$ différente de la pression d'air $p_{1}$ existant à l'entrée du puits.

Dans tous les essais, la valeur de $p_{1}$ coïncidait pratiquement avec la pression atmosphérique, puisque les pertes de charge de l'appareil de mesure du débit d'air $\mathrm{Q}_{a}$ (fig. 2) étaient très faibles. Dans cet appareil, la totalité de l'air pénétrant dans le puits devait passer par l'anémomètre (fig. 2). La relation entre le débit d'air et les valeurs indiquées par l'anémomètre a été établie en fonction d'un étalonnage préliminaire. Les débits d'air $\mathrm{Q}_{a}^{\prime}$ ont également été mesurés, à la sortie du cylindre, au moyen d'un diaphragme situé à l'aval du robinet dans la conduite d'air au sommet du cylindre (fig. 1).

Les résultats recueillis au moyen de ce diaphragme ne seront pas évoqués par la suite; notons simplement que les débits d'air $Q^{\prime}{ }_{a}$ s'écoulant par le diaphragme étaient inférieurs à ceux mesurés par l'anémomètre, la différence entre ces deux valeurs représentant le débit d'air entraîné par le tuyau horizontal. En général, aux grandes valeurs de $\delta$, de faibles quantités d'air ont été entraînées par l'eau sous forme de bulles en suspension; par contre, pour des faibles valeurs de $\delta$, les débits d'air augmentaient notablement, et il se formait une couche d'air immédiatement au-dessous des génératrices supérieures du tuyau horizontal.

Les débits d'eau $Q$ ont été mesurés au moyen d'un Venturimètre du circuit normal du laboratoire.

Les quantités mesurées pendant les essais sont indiquées sur la figure 1. Outre les débits d'air et d'eau, les mesures ont également porté sur les grandeurs suivantes :

- la charge $h_{1}$, sur le fond du cylindre;

- la charge $h_{2}$, au manomètre placé au sommet du cylindre;

- la hauteur $\delta$ du plan d'eau à l'intérieur du cylindre. of the shaft in most of the tests deviated the jet towards the wall of the cylinder, thus facilitating the air separation. The water discharged from the bottom of the cylinder through a horizontal pipe, while the air was released from the top through a valve and an orifice. The height of water in the cylinder was regulated by a control valve at the end of the horizontal pipe, and the pressure of the overlying air by the valve in the air pipe. In this way it was possible to obtain a pressure $p_{2}$ in the upper portion of the cylinder differing from the air pressure $p_{1}$ at the inlet of the shaft.

In all the tests, the value of $p_{1}$ practically coincided with the atmospheric pressure, as the losses of pressure in the apparatus (fig. 2) for measuring the air flow $Q_{a}$ were very small. In this apparatus all the air entering the shaft had to pass through the anemometer (fig. 2). A preliminary calibration gave the relation between air flows and the readings on the anemometer. Air flows $Q^{\prime}$ were also measured at the cylinder outlet by means of the orifice downstream from

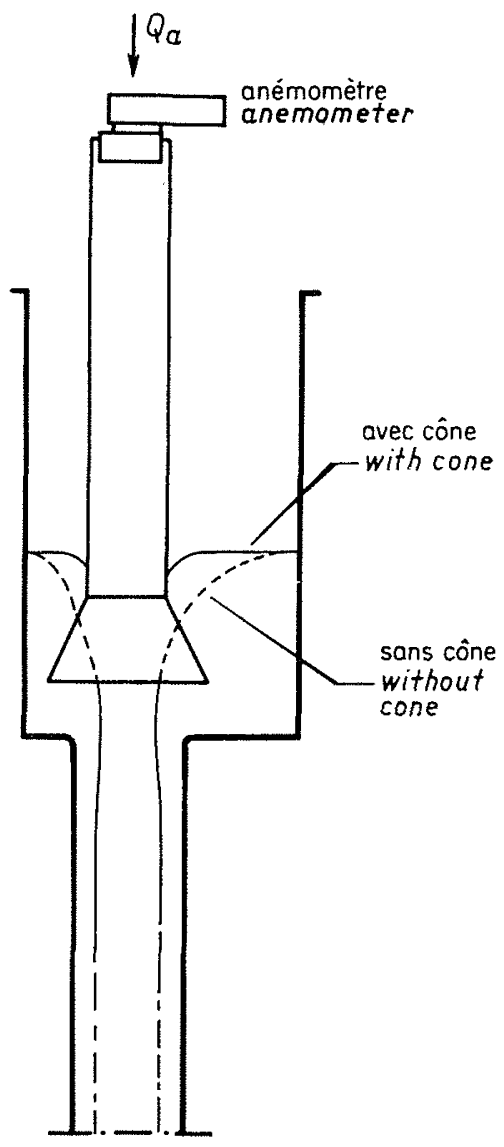

FIG. 2

Dispositifs de mesure. Arrangement used for measuring. 


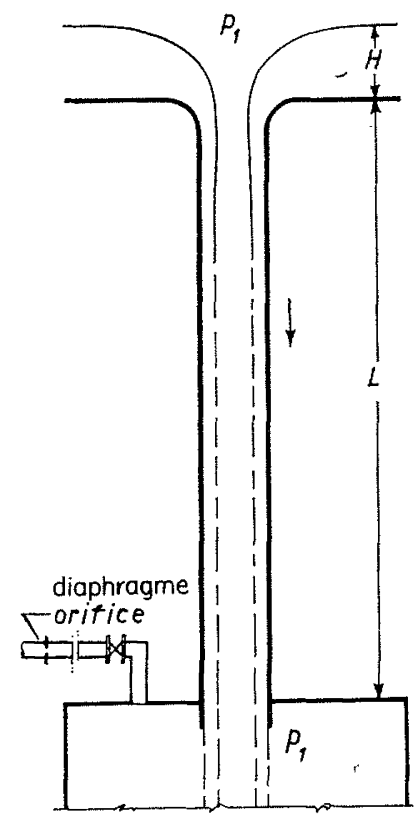

FIG. 3

Puits à sortie libre.

Shaft with a free exit.

La charge $h_{1}$ et les hauteurs $\delta$ ont été déterminées par rapport à l'axe du tuyau horizontal. La hauteur $\delta$ a été mesurée par observation directe à travers des vitres aménagées dans les parois en acier du cylindre.

Il a été déduit, pour la pression à la sortie du puits les relations suivantes : $p_{2}=\gamma h_{2}$ pour un puits vertical débouchant à l'air libre, et

$$
p_{2}=\gamma\left(h_{1}-0,63\right)
$$

pour un puits vertical débouchant sous la surface de l'eau. $\gamma$ étant la densité de l'eau

Malgré l'air contenu dans l'eau à l'intérieur du cylindre, la charge $h_{1}$ n'était guère différente de la somme $\delta+h_{2}$, du moins à l'intérieur des limites entre lesquelles l'on pouvait encore distinguer les oscillations des surfaces d'eau à l'intérieur du cylindre et dans les piézomètres. D'où, également :

$$
p_{2}=\gamma\left(\delta+h_{2}-0,63\right)
$$

\section{Modes d'écoulement}

Avec l'installation décrite, il a été possible d'obtenir plusieurs modes d'écoulement différents.

Lorsque le puits vertical débouchait au-dessous du plan d'eau à l'intérieur du cylindre, et le robinet d'air étant ouvert (soit : $h_{2}=0$ ), un courant d'eau dirigé dans le sens tangentiel par l'entrée en spirale, s'écoulait le long de la paroi intérieure du puits, en y adhérant, en laissant de la place à l'intérieur pour l'écoulement d'air (fig. 3). Dans ces conditions, on pouvait considérer que l'eau se trouvait en chute libre à l'intéricur du puits.

Lorsque le robinet d'air au sommet du cylindre était partiellement fermé, l'eau restait en the valve in the air pipe at the top of the cylinder (fig. 1).

The data collected at this orifice will not be discussed in the following; the only point to note in this connection is that air discharges $\mathrm{Q}_{a}^{\prime}$ through the orifice were smaller than those measured by the anemometer, the difference giving the flow of air entrained in the horizontal pipe. In general, at large values of $\delta$, small air flows were entrained by the water in the form of bubbles in suspension; at small values of $\delta$, the air flows increased noticeably, and an air layer formed immediately below the upper generatrices of the horizontal pipe.

Water discharges $Q$ were measured with a Venturimeter in the laboratory water circuit.

Figure 1 shows quantities measured during the tests. In addition to air and water flows, the following were measured:

The head $h_{1}$, on the bottom of the cylinder;

The head $h_{2}$, at the manometer inserted at the top of the cylinder;

The height $\delta$ of the water suface in the cylinder.

Head $h_{1}$, and heights $\delta$ were referred to the axis of the horizontal pipe. Height $\delta$ was measured by taking direct readings through glass windows provided in the steel cylinder wall.

The pressure at the exit of the shaft was found to be $p_{2}=\gamma h_{2}, \gamma$ being the specific gravity of the water, for the shaft discharging into air, and $p_{2}=\gamma\left(h_{1}-0.63\right)$, when discharging below the water surface.

Notwithstanding the air content of the water in the cylinder, head $h_{1}$ did not differ from the sum of $\delta+h_{2}$, at least as the oscillations of the water surfaces in the cylinder and piezometers let discern. Hence, also :

$$
p_{2}=\gamma\left(\delta+h_{2}-0.63\right)
$$

\section{Types of flow}

It was possible to obtain many different types of flow in the above installation.

With the shaft discharging above the water surface in the cylinder, and with the air valve open, (i.e. $h_{2}=0$ ) a stream of water directed tangentially by the spiral inlet [5] flowed down the shaft, adhering to its inside wall and leaving a free space inside it for the air stream (fig. 3). The water could thus be considered as falling freely inside the shaft.

With the air valve at the top of the cylinder partially closed, the water maintained its free fall until the pressure $p_{2}$ was only a little larger than $p_{1}$. But if the air valve was closed and $p_{2}$ 
chute libre, jusqu'à ce que la pression $p_{2}$ soit devenue seulement un peu plus élevée que la pression $p_{1}$. Mais, lorsqu'on fermait le robinet d'air, et que la valeur de $p_{2}$ dépassait suffisamment celle de $p_{1}$, le mélange air et eau remplissait de nouveau iñtégralement toute la section de la partie inférieure du puits. Lorsque $p_{2}$ continuait à augmenter, le mélange d'air et d'eau remontait à l'intérieur du puits (fig. 4), et remplissait sa partie terminale, de longueur $a$. La partic supérieure du mélange se trouvait violemment perturbée par des tourbillons et de grosses bulles d'air. Puisque cette partie de l'écoulement ressemblait à l'écoulement à l'intérieur d'un ressaut hydraulique bien évolué, on peut dire qu'un ressaut se formait à l'intérieur de la chute libre de l'eau dans le puits. On constatait, à l'aval du ressaut, la présence de grosses bulles d'air dans l'eau.

Lorsque le puits débouchait à l'air, presque toute la séparation du mélange air et eau s'effectuait dans la partie supérieure du cylindre (fig. 4). L'eau du jet débitant du puits, se mélangeait à la masse d'eau contenue dans le cylin- increased sufficiently above the value of $p_{1}$, the air and water mixture filled the whole section of the lower portion of the shaft. At a further increase of $p_{2}$, the air and water mixture rose inside the shaft (fig. 4), and filled its end portion of length $a$. The upper portion of mixed air and water was violently disturbed by vortices and big air bubbles. As this portion of flow was similar to that in a well-developed hydraulic jump, it can be said that a jump formed after the free fall of water in the shaft. Downstream of the jump, there appeared a water flow containing, many air bubbles.

With the shaft discharging into air, the mixture of air and water separated out practically entirely in the upper portion of the cylinder (fig. 4). The water of the jet from the shaft merged with the water in the bottom of the cylinder, while the released air discharged through the air valve.

When the shaft discharged below the water surface in the cylinder, a hydraulic jump invariably formed as expected, which, at sufficiently large values of $a$, was followed by a column of

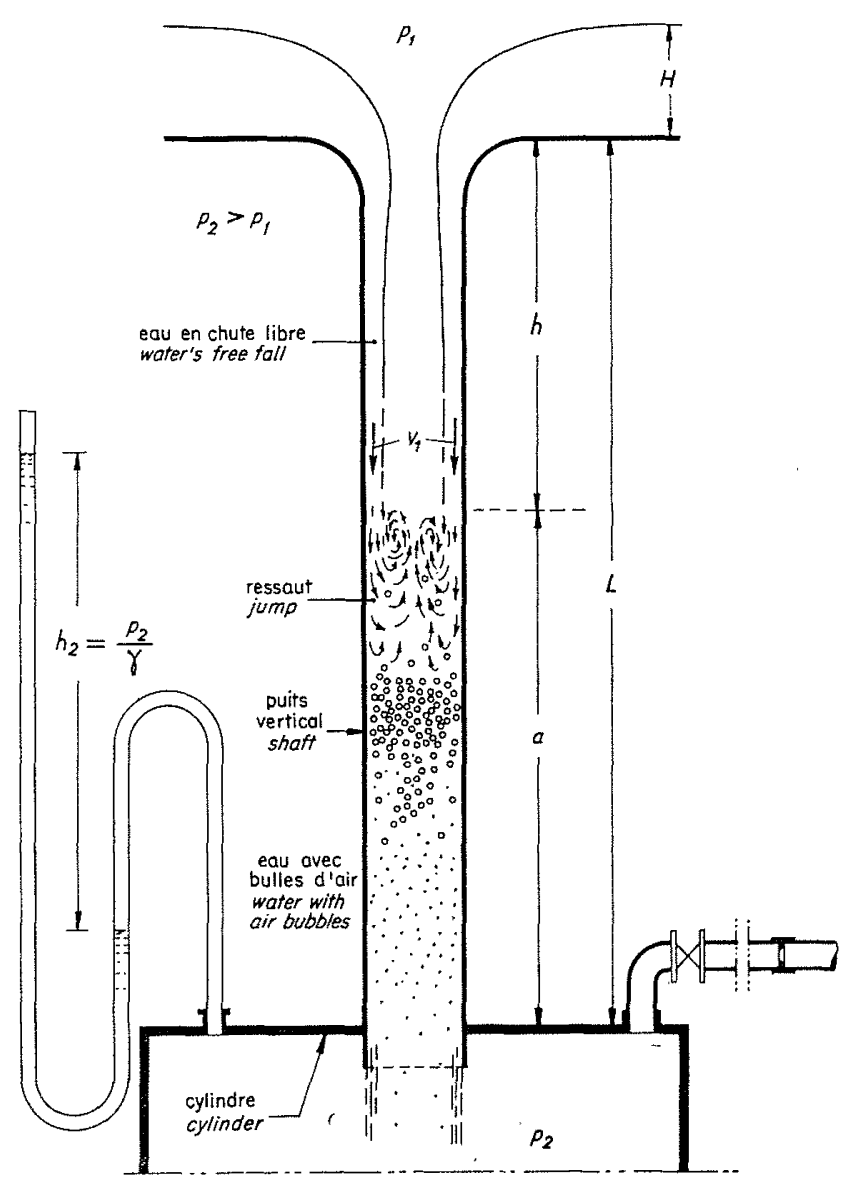

Fig. 4

Puits débouchant dans de l'air sous pression. Shaft discharging into air under pressure. 
dre, au-dessous de la surface de celle-ci, alors que l'air libéré s'évacuait par le robinet d'air.

Lorsque le puits débouchait au-dessus de la surface de l'eau, il se formait toujours, comme attendu, un ressaut hydraulique suivi, aux valeurs suffisamment élevées de $a$, par une colonne d'eau contenant des bulles d'air (fig. 5). A la sortie du puits, la presque totalité de l'air se séparait de l'eau, et remontait vers la partie supérieure du cylindre, sous la forme de grosses bulles.

\section{Régime d'entraînement d'air, avec de l'eau en chute libre à l'intérieur du puits}

Pour l'examen de ce cas (fig. 3), il convient de définir le débit d'eau $Q_{m}$, que pourrait transporter un tuyau du même diamètre que le puits sans entraînement d'air, et pour une perte unitaire de l'ordre de $1: 1$.

En négligeant les pertes de charge à l'entrée, on peut écrire :

$$
\mathrm{H}+\mathrm{L}=\mathrm{Q}_{m}^{2}\left(\frac{\alpha}{2 g \sigma^{2}}+\frac{\mathrm{L}}{\mathrm{K}^{2} \mathrm{R}^{4 / 3} \sigma^{2}}\right)
$$

dans laquelle $\mathrm{L}$ est la longueur du puits, $\mathrm{H}$ la hauteur d'eau à l'entrée, $\sigma$ et $\mathrm{R}$ sont, respectivement, la section et le rayon hydraulique du puits. $K$ est la valeur réciproque du coefficient de Manning, et $\alpha$ est un coefficient expérimental supposé égal à 1 .

Lorsque le débit d'eau $Q$ était beaucoup plus petit que $Q_{m}$, le courant d'eau en chute libre et adhérant à la paroi du puits laissait suffisamment d'espace libre pour permettre l'écoulement de l'air de haut en bas au centre de la conduite.

Lorsque $\mathrm{Q}$ n'était pas très différent de $\mathrm{Q}_{m}$, la section $d u$ «noyau » d'air commençait à varier, et se désintégrait parfois sous la forme de grosses bulles d'air (et/ou de poches d'air) descendant avec l'eau qui les entourait.

Le débit d'eau $Q_{m}$, et les rapports $Q / Q_{m}$ et $\left(\mathrm{Q}+\mathrm{Q}_{a}\right) / \mathrm{Q}_{m}$ ont été calculés pour toutes les courbes $\left(\mathrm{Q}, \mathrm{Q}_{a}\right)$ obtenues lors des expériences réalisées à Naples [1], par Kalinske [2], et par Marquenet [3] (2) sur l'entraînement d'air dans les puits verticaux.

Les courbes $\left[\left(\mathrm{Q} / \mathrm{Q}_{m}\right),\left[\left(\mathrm{Q}+\mathrm{Q}_{a}\right) / \mathrm{Q}_{m}\right]\right]$ ainsi déduites sont situćes à l'intérieur de la zone

(2) Les données de Kalinske et de Marquenet ont été tirées des graphiques annexés aux mémoires de ces auteurs.

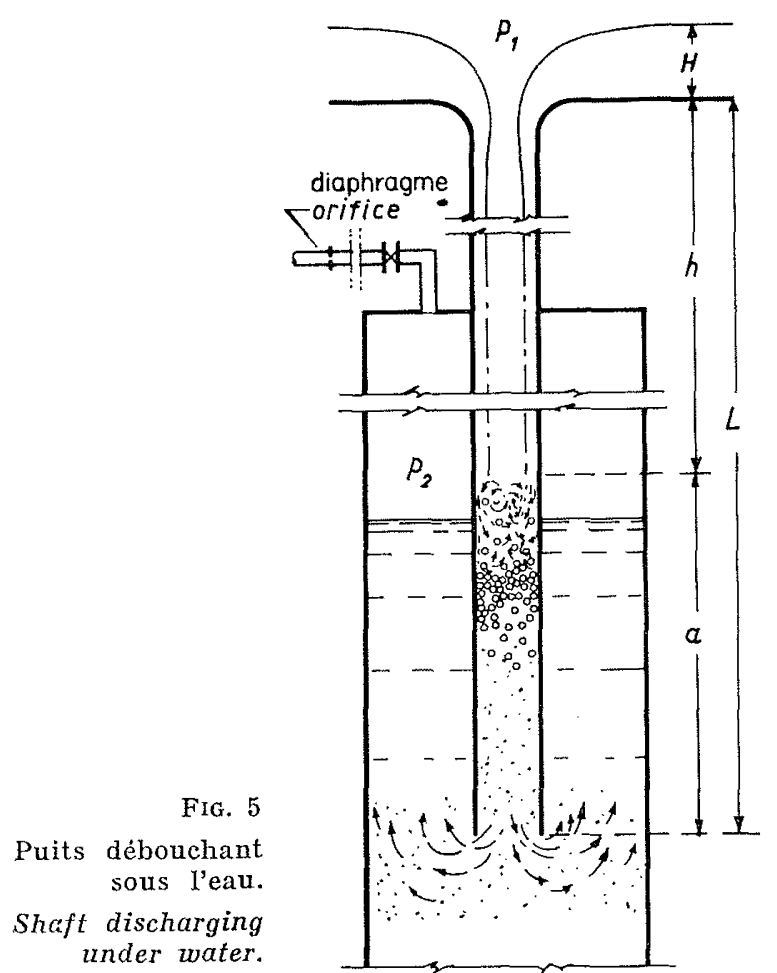

water with air bubbles (fig. 5). At the outlet from the shaft, almost all the air separated from the water and rose towards the upper portion of the cylinder in the form of large bubbles.

\section{Air entrainment conditions with water falling freely in the shaft}

In order to discuss this case (fig. 3 ), it is convenient to define the flow of water $Q_{m}$, which a pipe of the diameter of the shaft could convey, in the absence of air entrainment, with a unit loss about $1: 1$.

Neglecting the head losses at the entrance, the following can be written:

$$
\mathrm{H}+\mathrm{L}=\mathrm{Q}_{n}^{2}\left(\frac{\alpha}{2 g \sigma^{2}}+\frac{\mathrm{L}}{\mathrm{K}^{2} \mathrm{R}^{4 / 3} \sigma^{2}}\right)
$$

$L$ being the length of the shaft, $H$ the depth of water in the inlet, $\sigma$ and $R$ respectively the crosssectional area and hydraulic radius of the shaft, $K$ the reciprocal of Manning's coefficient, $\alpha$ an experimental coefficient that was taken equal to 1 .

When the flow of water $Q$ was much smaller than $\mathbf{Q}_{m}$, the stream of water falling freely and adhering to the wall of the shaft left sufficient room for the air flow down the centre.

When $\mathrm{Q}$ differed comparatively little from $Q_{n}$, the cross-sectional area of the central air core began to vary and sometimes broke up into large 


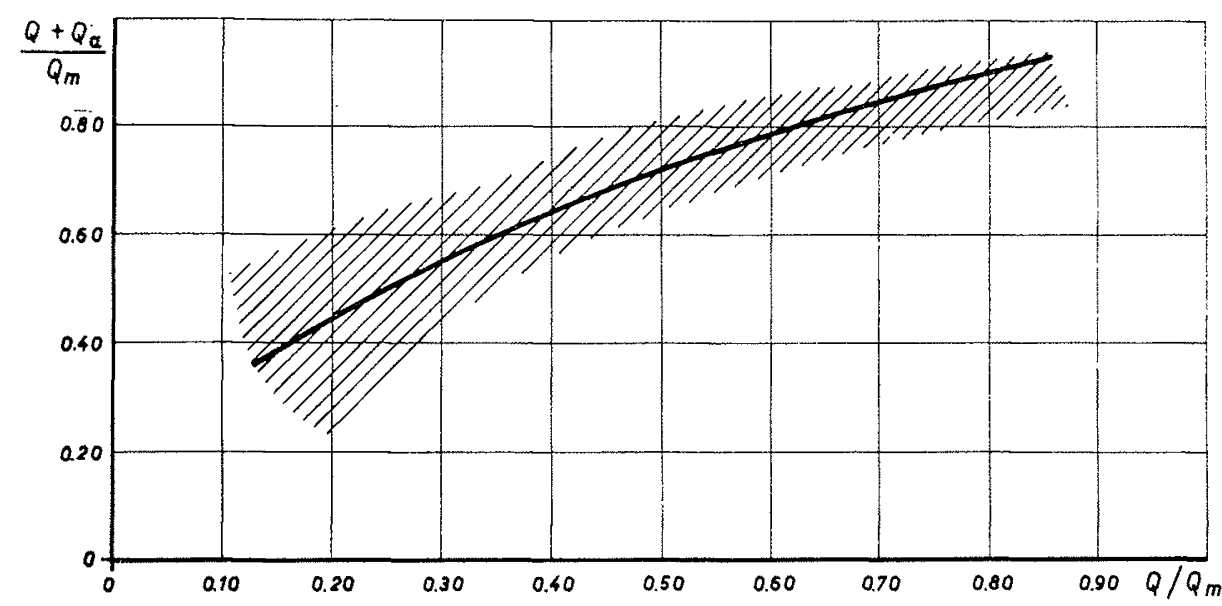

FIG. 6

Courbe $\left[\left(Q+Q_{a}\right) / Q_{m}, Q / Q_{m}\right]$ pour un puits à sortie libre. Curve $\left[\left(Q+Q_{\mathrm{a}}\right): / Q_{\mathrm{m}}, Q / Q_{\mathrm{m}}\right]$ for a shaft with a free exit.

hachurée de l'abaque de la figure 6. La courbe continue représentée pour la relation:

$$
\frac{\mathrm{Q}+\mathrm{Q}_{a}}{\mathrm{Q}_{m}}=\left(\frac{\mathrm{Q}}{\mathrm{Q}_{m}}\right)^{0,5}
$$

fournit une bonne interpolation des résultats expérimentaux. Elle permet de calculer $\mathrm{Q}_{a}$ lorsque $Q$ est différent de $\mathbf{Q}_{m}$.

Pour $Q<<Q_{m}$, la surface de séparation entre l'air et l'eau devient discontinue peu après l'entrée. D'une manière similaire à ce qui se produit dans les canaux à pente raide [6], des bulles d'air pénètrent dans l'eau, et des gouttes d'eau commencent à rejaillir dans l'espace occupé par l'air. Le «noyau » d'air se trouve accéléré vers le bas par l'échange des quantités de mouvement avec l'écoulement d'eau.

Si l'on admet que, dans des puits verticaux de très grande longueur, l'air atteint, à cause de l'échange de quantité de mouvement, la même vitesse moyenne $V_{1}$ que l'écoulement d'eau à la paroi, on a, pour le débit d'air maximal :

$$
\mathrm{Q}_{a_{11 \mathrm{im}}}=\frac{\pi d_{0}^{2}}{4} \mathrm{~V}_{1}
$$

$d_{0}$ étant le diamètre du «noyau» d'air.

En outre, on peut calculer $V_{1}$, pour des puits de grande longueur et de diamètre $D$, d'après la relation :

$$
\mathrm{V}_{1}=\mathrm{K}^{3 / 5}\left(\frac{\mathrm{Q}}{\pi \mathrm{D}}\right)^{2 / 5}
$$

air bubbles and/or air pockets moving downwards with the surrounding water.

The flow of water $Q_{m}$ and ratios

$$
\left(\mathrm{Q} / \mathrm{Q}_{m}\right) \text { and }\left[\left(\mathrm{Q}+\mathrm{Q}_{a}\right) / \mathrm{Q}_{m}\right]
$$

were calculated for all the curves $\left(Q, Q_{d}\right)$ obtained from experiments on air entrainment in shafts carried out at Naples [1], by Kalinske [2] and by Marquenet [3] (2).

The curves $\left(\mathrm{Q} / \mathrm{Q}_{m}\right),\left[\left(\mathrm{Q}+\mathrm{Q}_{a}\right) / \mathrm{Q}_{m}\right]$ thus deduced lie within the shaded area in figure 6 . The continuous curve represented by the relation

$$
\frac{\mathrm{Q}+\mathrm{Q}_{a}}{\mathrm{Q}_{m}}=\left(\frac{\mathrm{Q}}{\mathrm{Q}_{m}}\right)^{0,5}
$$

gives a good interpolation of experimental results. It can ben used for calculating $Q_{a}$, when $Q$ differs from $Q_{m}$.

For $Q<<Q_{m}$, the surface of separation between air and water in the shaft loses its continuity soon after the inlet. Similarly to what happens in steep channels [6], air bubbles penetrate into the water and water drops start flying about in the air. The air core is accelerated downwards by the exchange of momentum with the water flow.

Assuming that, because of the exchange of momentum, the air in very long shafts, reaches the same mean velocity $V_{1}$ as the stream of water at the wall, the maximum air flow then becomes:

$$
\mathrm{Q}_{a_{\mathrm{L}} \text { 1im. }}=\frac{\pi d_{0}{ }^{2}}{4} \mathrm{~V}_{1}
$$

where $d_{0}$ is the diameter of the air core.

(2) Data of Kalinske and Marquenet were deduced from graphs of their papers. 
L'équation (4) se réduit à la forme simplifiée :

$$
\mathrm{Q}_{a \mathrm{im}}=\frac{\pi \mathrm{D}^{2}}{4} \mathrm{~V}_{1}-\mathrm{Q}
$$

Ce débit maximal ne peut être obtenu que lors que le puits est très long, et que $p_{1}=p_{2}$.

Des essais réalisés avec $p_{1} \cong p_{2}$ ont montré que le débit d'air $\mathrm{Q}_{a}$ dépend uniquement de la longueur de la conduite verticale, c'est-à-dire du rapport $L / D$. Tous les résultats expérimentaux disponibles sont, dans l'abaque

$$
\left[\left(\mathrm{Q}_{a} / \mathrm{Q}_{a \lim }\right),(\mathrm{D} / \mathrm{L})\right]
$$

(fig. 7), groupés à l'intérieur d'une bande étroite, dans laquelle on arrive tout juste à intercaler une courbe moyenne de l'expression :

$$
\frac{\mathrm{Q}_{a}}{Q_{a \lim }}=0,04\left(\frac{\mathrm{D}}{\mathrm{L}}\right)^{-2 / 3}
$$

La relation (6) tient compte du fait que $Q_{a}$ dépend de la longueur limitée du puits; elle n'est valable que si, pratiquement, l'écoulement d'air n'a aucune résistance à vaincre.

Dans les essais effectués à Naples, le débit d'air diminuait subitement lorsque le robinet d'air au sommet du cylindre était à peine ouvert, de sorte que $p_{2}>p_{1}$. Lorsque, par exemple, on avait $0,02 \leqslant\left[\left(p_{2}-p_{1}\right) / \gamma\right] \leqslant 0,10 \mathrm{~m}$, l'eau continuait à tomber en chute libre à l'intérieur du puits, mais $\mathrm{Q}_{a}$ se trouvait réduit au $1 / 4$, ou même au $1 / 5^{\text {e }}$ de la valeur de $Q_{a}$ obtenue lorsque $p_{1} \cong p_{2}$. De même, les valeurs obtenues pour $\mathbf{Q}_{a}$ lorsque la section terminale du puits était complètement libre, étaient plus élevées que celles obtenues lorsque ladite extrémité comportait un defflecteur (fig. 1 ).
Moreover, for very long shafts of internal diameter $\mathrm{D}, \mathrm{V}_{1}$ can be calculated [8] according to:

$$
\mathrm{V}_{1}=\mathrm{K}^{3 / 5}\left(\frac{\mathrm{Q}}{\pi \mathrm{D}}\right)^{2 / 5}
$$

Equation (4) simplifies to:

$$
\mathrm{Q}_{u \lim }=\frac{\pi \mathrm{D}^{2}}{4} \mathrm{~V}_{1}-\mathrm{Q}
$$

This maximum discharge can only be obtained when the shaft is very long and when $p_{1}=p_{2}$.

Tests in which $p_{1} \cong p_{2}$ showed that the air flow $Q_{a}$ depends only on the length of the shaft and, for that, on the ratio $L / D$. All the available experimental points, in a diagram

$$
\left[\left(\mathrm{Q}_{a} / \mathrm{Q}_{a \lim .}\right),(\mathrm{D} / \mathrm{L})\right]
$$

(fig. 7), are crowded together in a narrow band, in which one can just interpolate a mean curve of the expression:

$$
\frac{\mathrm{Q}_{\pi}}{Q_{a 1 \mathrm{im}}}=0.04\left(\frac{\mathrm{D}}{\mathrm{L}}\right)^{-2 / 3}
$$

Relation (6) allows for the dependence of $Q_{a}$ on the finite length of the shaft: it is only valid if, to all practical intents and purposes, the air flow does not have to overcome any resistance.

In the Naples experiments, when the air valve at the top of the cylinder was left nearly closed, so that $p_{2}>p_{1}$, the air flow suddenly decreased. When, for instance,

$$
0.02 \leqslant\left[\left(p_{2}-p_{1}\right) / \varphi\right] \leqslant 0.10 \mathrm{~m},
$$

the water continued to fall freely in the shaft, but $Q_{a}$ was reduced to as little as a quarter or a fifth of the $\mathrm{Q}_{a}$ value obtained with $p_{1} \cong p_{2}$. Similarly, the values of $Q_{u}$ obtained when the terminal section of the shaft was completely free were larger than those obtained with the deflector fitted at that point (fig. 1).

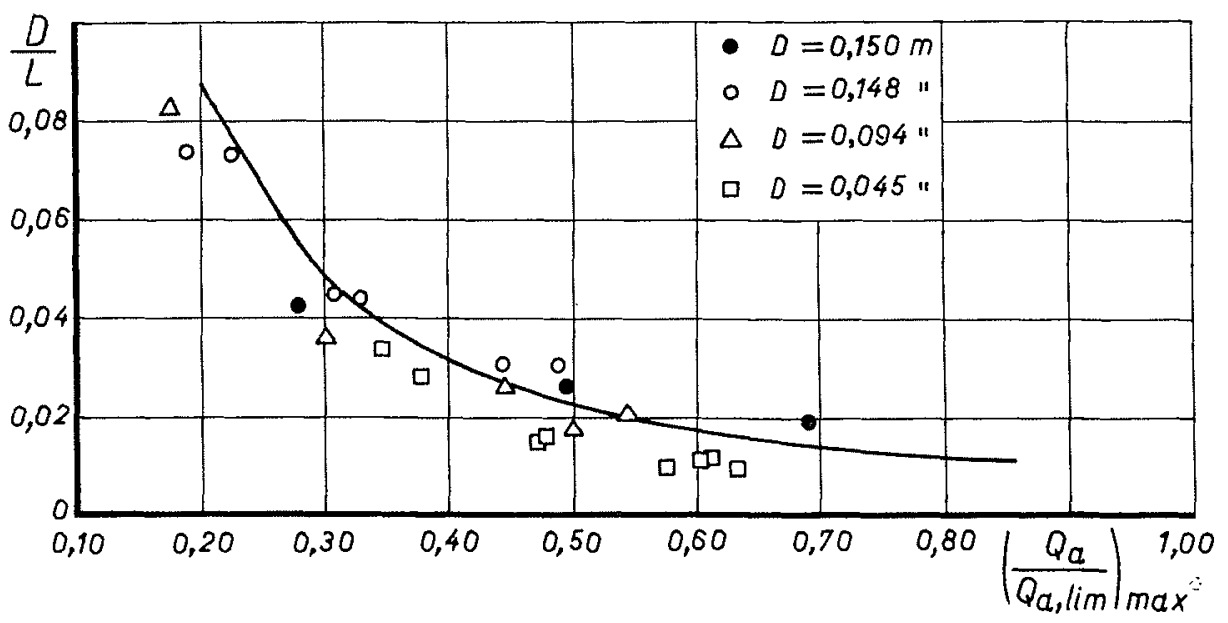

Fig. 7

Courbe $\left[Q_{a} / Q_{a 1 \mathrm{~m}}, h / \mathrm{h} / \mathrm{D}\right]$ pour un puits à sortie libre. Curve $\left[Q_{\mathrm{a}} / Q_{\mathrm{a} 1 \mathrm{~m}}, \mathrm{~h} / D\right]$ for a shaft with a free exit. 


\section{Régime d'entraînement d'air, en présence d'un ressaut hydraulique dans le puits}

Le régime décrit, dans lequel l'eau tombe en chute libre sur toute la hauteur du puits, est très instable lorsque $p_{1}<p_{2}$; dans ces conditions, un ressaut apparaît également à l'extrémité du puits pour de très faibles valeurs de $p_{2}-p_{1}$.

Lorsque $p_{2}-p_{1}$ augmente, le ressaut atteint sa longueur totale, étant (ainsi que nous l'avons signalé plus haut) suivi d'eau contenant des bulles d'air. On peut, généralement, considérer que le poids de la colonne d'air et d'eau équilibre la différence des pressions $p_{2}-p_{1}$.

On peut déterminer ce poids en calculant le pourcentage moyen $\rho$ de l'eau, contenu dans la colonne d'air et d'eau occupant la partie inférieure $a$ du puits.

En négligeant le poids de l'air, on obtient, en appliquant l'équation de quantité de mouvement à la colonne d'air et d'eau :

$$
\frac{\gamma}{g} \mathrm{QV}_{1}+\rho \gamma a \sigma=\gamma \sigma h_{2}+\frac{\gamma}{g} \frac{\mathrm{Q}}{\rho \sigma^{2}}
$$

$\gamma$ étant la densité de l'eau.

Dans l'essai effectué à Naples, $a, Q, \sigma$ et $h_{2}$ étaient connus, et $\mathrm{V}_{1}$ a été déduit suivant $\mathrm{Ka}-$

\section{Air entrainment conditions with a hydraulic jump in the shaft}

The above condition in which water is falling freely down the whole shaft is very unstable if $p_{1}<p_{2}$; in this case, a jump also appears at the end of the shaft at very small values of $p_{2}-p_{1}$.

If $p_{2}-p_{1}$ increases, the jump develops to its full length and is then, as stated above, followed by water containing air bubbles. It can be said that, in general, the weight of the air and water column counterbalances the difference of pressure $p_{2}-p_{1}$.

This weight can be found by calculating the average water percentage $\bullet$ in the air-and-water column filling the lower portion $a$ of the shaft.

Neglecting air weight, the momentum equation applied to the air-and-water column gives:

$$
\frac{\gamma}{g} \mathrm{QV}_{1}+\rho \gamma a \sigma=\gamma \sigma h_{2}+\frac{\gamma}{g} \frac{\mathrm{Q}}{\rho \sigma^{2}}
$$

$\gamma$ being the specific gravity of water.

In the Naples tests, $a, \mathrm{Q}, \sigma$ and $h_{2}$ were known, and $V_{1}$ was deduced as described by Kalinske

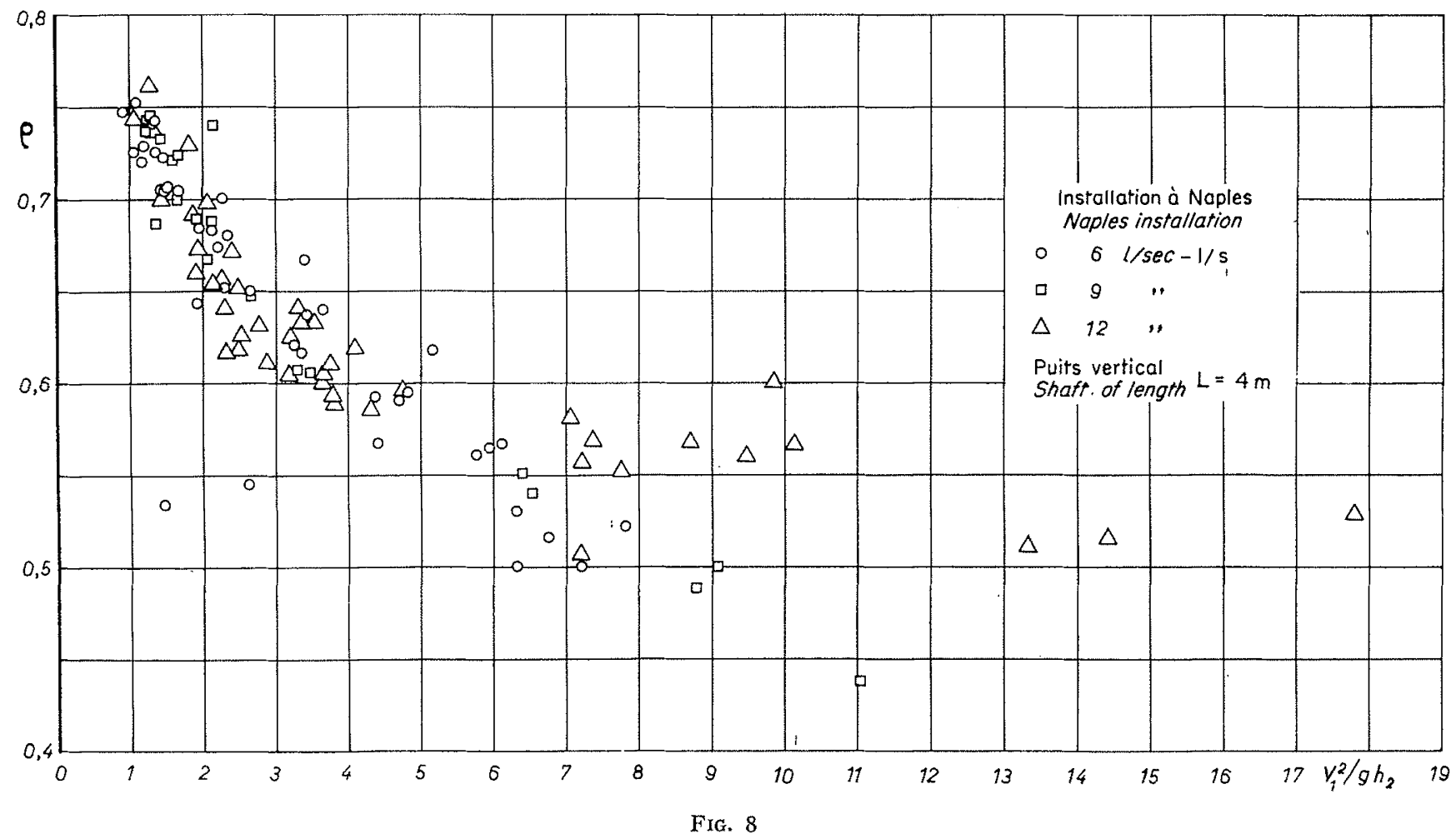

Courbe $\left[\mathrm{V}_{1}^{2} / g h, \varrho\right]$ avec ressaut hydraulique dans le puits. Curve $\left[\mathrm{V}_{1}^{2} / \mathrm{gh}, \mathrm{Q}\right]$ with jump in the shaft. 
linske et Dawson [8](3). Notons en passant que $V_{1}$ augmente d'abord rapidement en fonction de $h$ mais que sa valeur devient ensuite quasi constante, étant très rapprochée de celle donnée par (5).

Les valeurs de $\rho$, obtenues d'après l'équation (7), sont portées en fonction de $\mathrm{V}_{1}^{2} / 2 g h_{2}$ sur la figure 8 . Puisque $V_{1}$ ne varie pas beaucoup le long de la conduite verticale, le pourcentage d'eau diminue progressivement, lorsque $h_{2}$ décroît.

Les données expérimentales montrent, en outre, que $a=1,1 h_{2}$ à $1,3 h_{2}$, à condition toutefois, que les valeurs de $a$ et de $h_{2}$ soient suffisamment grandes (voir également Wittman et Bellina [7]) et que $a=h_{2}$ lorsque ces valeurs sont faibles.

Ceci permet cette conclusion que, lorsque la colonne d'air et d'eau renferme entièrement le ressaut, o $\gamma \alpha \cong \gamma h_{2}=p_{2}-p_{1}$. Lorsque la longueur $a$ de la colonne est réduite et ne renferme qu'un ressaut partiel, le pourcentage d'air

$$
(1-p)
$$

augmente, et le poids de la colonne est inférieur à $\left(p_{1}-p_{2}\right) / \gamma$.

La présence du ressaut, même à l'état partiel, favorise le mouvement de l'air, lorsque $p_{1}<p_{2}$. L'abaque de la figure 9 montre toutes les valeurs de $\mathrm{Q}_{a} / \mathrm{Q}$ obtenues lors des essais, avec

$$
p_{2}-p_{1}>0
$$

et, en présence d'un ressaut, portées en fonction des valeurs correspondantes de $h / D$. L'abaque comporte également des données provenant de Mavis et Laushey [4] (4). L'installation expérimentale de ces auteurs était analogue à celle utilisée à Naples, y compris l'alimentation comportant un dispositif assurant un écoulement en spirale.

Notons cependant que ces auteurs n'ont pas mesuré $\mathrm{Q}_{a}$, mais $\mathrm{Q}_{a}^{\prime}$ (le débit d'air par le robinet d'air et le diaphragme à l'aval du puits). Les rapports $Q_{a} / Q$ de Mavis et Laushey doivent donc être considérés comme étant légèrement moins élevés que les rapports réels.

La plupart des points sur l'abaque de la

(3) Le théorème de Bernoulli permet d'écrire :

$$
y=\frac{\mathrm{V}_{1}^{2}}{2 g}+\int_{0}^{y} \frac{\mathrm{V}_{1}^{2}(y)}{\mathrm{K}^{2}[\mathrm{D}-d(y)]^{4 / 3}} d y
$$

$y$ étant la hauteur de la section considérée au-dessous du plan d'eau à l'entrée, et $V_{1}(y)$ et $d(y)$ étant, respectivement, la vitesse de l'eau et le diamètre du «noyau» d'air en $y$.

D'autres données peuvent être tirées d'une étude non publiée intitulée «Usine d'Oraison - Puits de décharge Première étude» par l'E.D.F., R.E.H. Alpes-IV.

(4) Dans leur mémoire, Mavis et Laushey évaluent les valeurs réelles de $Q_{a}$ comme étant d'environ $5 \%$ plus élevées que les valeurs mesurées $Q^{\prime} a$. and Dawson [8] (3). Incidentally, $V_{1}$ first increases rapidly with $h$, but then becomes almost constant, its value being very similar to that given by $(5)$.

In figure 8 values of obtained with equation (7) are plotted against $V_{1}^{2} / 2 g h_{2}$. Since $V_{1}$ varies little along the shaft, the water percentage becomes smaller and smaller with decreasing $h_{2}$.

Moreover, experimental data show that $a=1.1$ to $1.3 h_{2}$, if their values are large enough, (see also Wittman and Bellina [7]) and $a=h_{2}$ if they are small.

Hence it can be stated that when the column of air and water completely encloses the jump, it is $\gamma_{\gamma} \alpha \cong \gamma h_{2}=p_{2}-p_{1}$. When the length of column $a$ is short and only encloses an incomplete jump, the air percentage $(1-0)$ increases, an the column weight is less than $\left[\left(p_{1}-p_{2}\right) / \gamma\right]$.

The presence of jump, even if incomplete, facilitates the air movement when $p_{1}<p_{2}$. In the diagram on figure 9 all the values of $Q_{a} / Q$ obtained in the tests with $p_{2}-p_{1}>0$ and jump are plotted against the corresponding $h / D$. Data of research carried out by Mavis and Laushey $[4]^{(4)}$ are also included. Their experimental apparatus was similar to that used at Naples, including the inlet producing spiral flow.

It should be noted, however, that these authors did not measure $\mathrm{Q}_{a}$, but $\mathrm{Q}^{\prime}$ (air discharge through the air valve and orifice downstream of the shaft). Mavis and Laushey's ratios $\mathrm{Q}_{a} / \mathrm{Q}$ should therefore be considered a little lower than the real ratios.

Most of the points in figure 9 are concentrated around a curve represented by:

$$
\frac{\mathrm{Q}_{a}}{\mathrm{Q}}=0.022\left(\frac{h}{\mathrm{D}}\right)^{3 / 5}
$$

Three groups of points however, are well outside the curve, at rapidly increasing abscissae, this happens when $h / \mathrm{D}$ does not differ much from $\mathrm{L} / \mathrm{D}, \mathrm{L}$ being the length of shaft to which each group of points refers. In other words, the length $(a=\mathrm{L}-h)$ of the air-and-water column in the

(3) Applying Bernoulli's theorem, it can be written that :

$$
y=\frac{V_{1}^{2}}{2 g}+\int_{0}^{y} \frac{V_{1}^{2}(y)}{\mathrm{K}^{2}[\mathrm{D}-d(y)]^{4 / 3}} d y
$$

$y$ being the depth of section considered below the water surface in the inlet, and $V_{1}(y)$ and $d(y)$ the water velocity and diameter of the air core at $y$ respectively.

Other information can be found in an unpublished note on «Usine d'Oraison - Puits de décharge - Première étude» par Electricité de France, R.E.H. Alpes-IV.

(4) In their paper Mavis and Laushey estimate the real values of $Q_{a}$ as being about $5 \%$ higher than the measured values of $Q^{\prime}$. 
figure 9 sont concentrés autour d'une courbe représentée par l'équation :

$$
\frac{\mathrm{Q}_{a}}{\mathrm{Q}}=0,022\left(\frac{h}{\mathrm{D}}\right)^{3 / 5}
$$

Trois groupes de points s'écartent de cette courbe, dont les abscisses croissent très rapidement lorsque $h / \mathrm{D}$ n'est pas très différent de L/D, $\mathrm{L}$ étant la longueur du puits correspondant à chaque groupe de points. Ceci signifie que la longueur $(a==L-h)$ de la colonne d'air et d'eau dans le puits est très réduite, et que le ressaut n'est pas complètement formé. Ainsi que nous l'avons signalé plus haut, dans ces conditions, le pourcentage d'air à l'extrémité inférieure du puits est très élevé, et la vitesse $V_{1}$ de l'eau en chute shaft is very short, and the jump is not completely developed. As pointed out above, under these conditions, the air percentage at the lower end of the shaft is very high, and the velocity $V_{1}$ of the freely falling water is only partially damped. (See also Mavis and Laushey [4]). Hence the air flow $Q_{a}$ increases as length $a$ decreases: for $a \rightarrow 0$ the values of $\mathrm{Q}_{a}$ approach those given by (6).

When length $a$ is large, the jump turbulence is damped above the lower end of the shaft and the air flow $Q_{a}$ is given by the movement of bubbles in the underlying air-and-water column.

The curve on figure 9 (Eq. 8) gives a good interpolation between the results of a large number of tests with fully-developed jump. Although

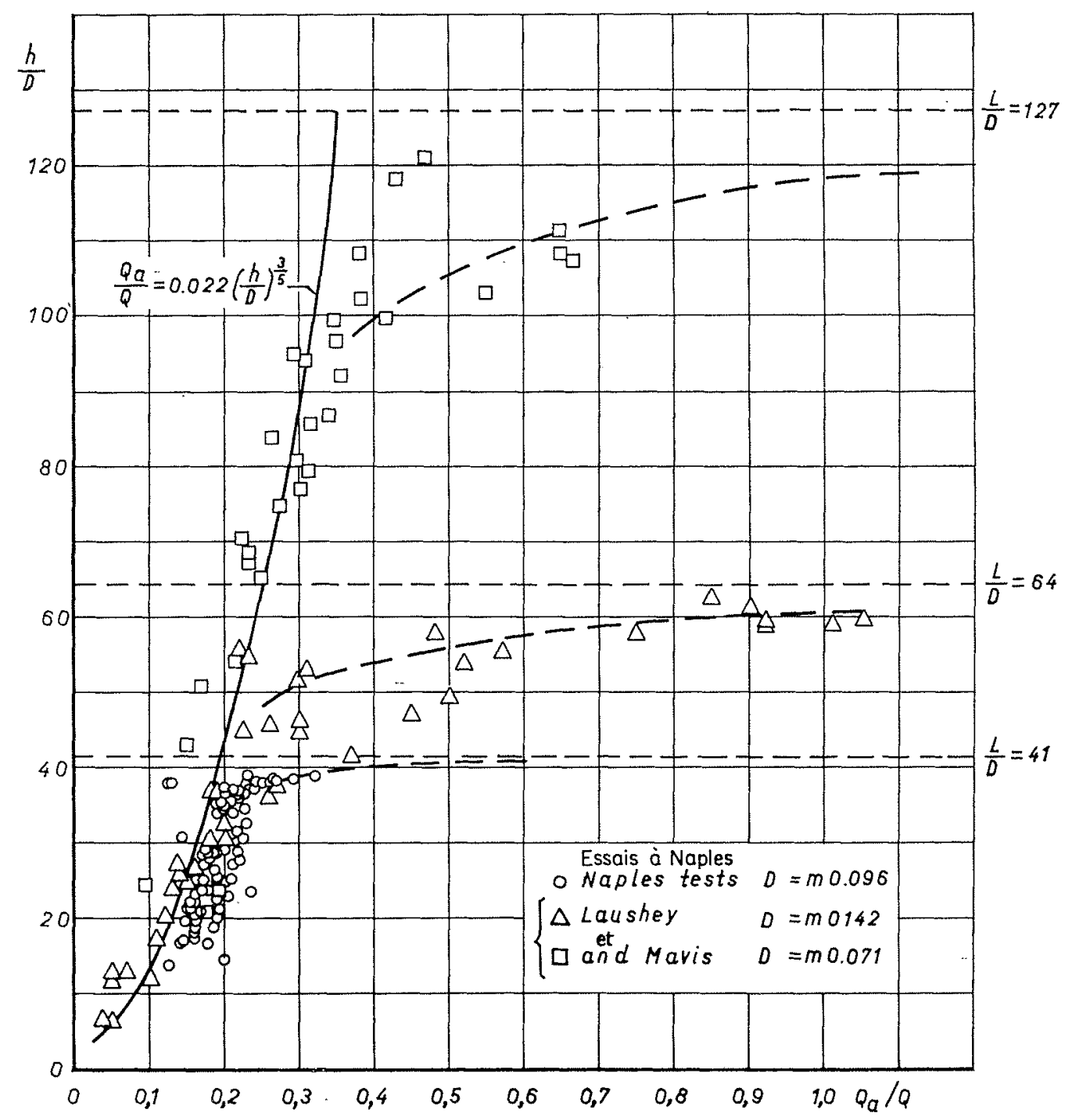

Fig. 9

Courbe $\left[Q_{a} / Q, h / D\right]$ avec ressaut hydraulique dans le puits. Curve $\left[Q_{\mathrm{a}} / Q, \mathrm{~h} / D\right]$ with jump in the shaft. 
libre n'est que partiellement amortie (voir également Mavis et Laushey [4]). Il s'ensuit que le débit d'air $\mathrm{Q}_{a}$ augmente à mesure que la longueur $a$ diminue; pour $a \rightarrow 0$, les valeurs de $Q_{a}$ s'approchent de celles données par (6).

Lorsque la longueur $a$ est importante, la turbulence du ressaut est amortie au-dessus de l'extrémité inférieure du puits, et le débit d'air $Q_{a}$ est donné par le mouvement des bulles à l'intérieur de la colonne d'air et d'eau sous-jacente.

La courbe (8) de l'abaque de la figure 9 représente une bonne interpolation des résultats de nombreux essais effectués avec un ressaut complètement formé. Les résultats d'essais isolés ont confirmé que $\mathrm{Q}_{a}$ est bien fonction de $h$, suivant la courbe (8), mais ils ont également mis en évidence plusieurs raisons pour la dispersion des points expérimentaux constatée sur l'abaque.

Les essais de Mavis et Laushey ont nettement démontré que, si l'écoulement à l'entrée du puits est radial, et non en spirale, le débit d'air augmente, toutes les autres grandeurs restant égales.

Les résultats des essais effectués à Naples sont présentés d'une manière plus détaillée sur la figure 10 . On y voit que $\mathrm{Q}_{a} / \mathrm{Q}$ diminue lorsque $\mathrm{Q}$ augmente, et que la longueur $a$ de la colonne d'air et d'eau est sans importance, à condition, toutefois, que cette colonne renferme le ressaut complet.

Des essais ont également été effectués à Naples à l'aide de l'installation montrée par la figure 11 . Les valeurs de $Q_{a} / Q$ ainsi obtenues étaient plus élevées que celles obtenues avec l'installation de la figure 1, Q et $h$ étant les mêmes dans les deux cas.

On peut en déduire que, lorsqu'il se forme un ressaut complet à l'intérieur du puits, l'entrâ̂-

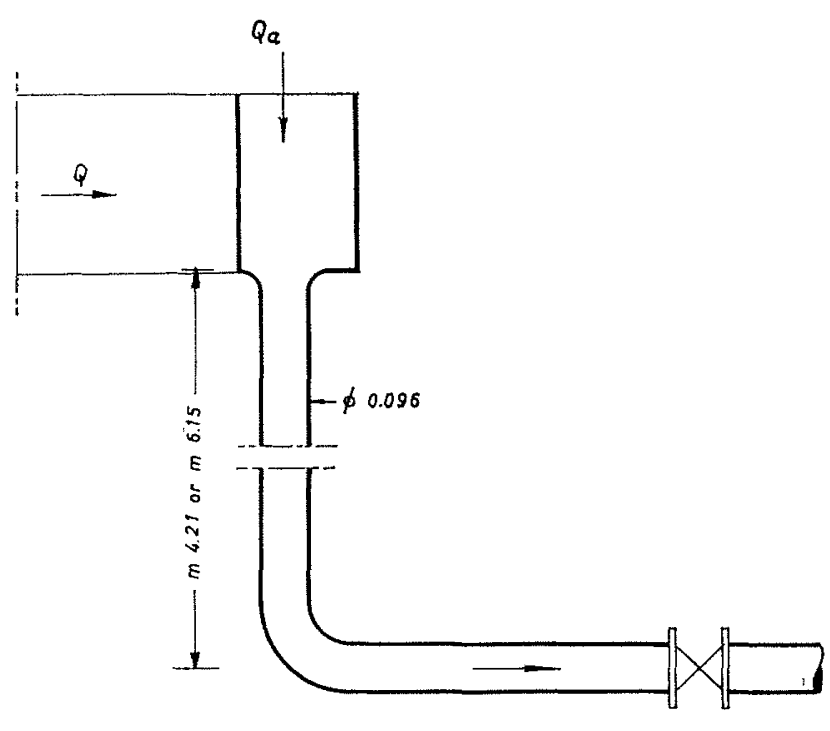

FIG. 11

Installation avec puits suivi d'une conduite horizontale. Apparatus with the shaft followed by a horizontal pipe.

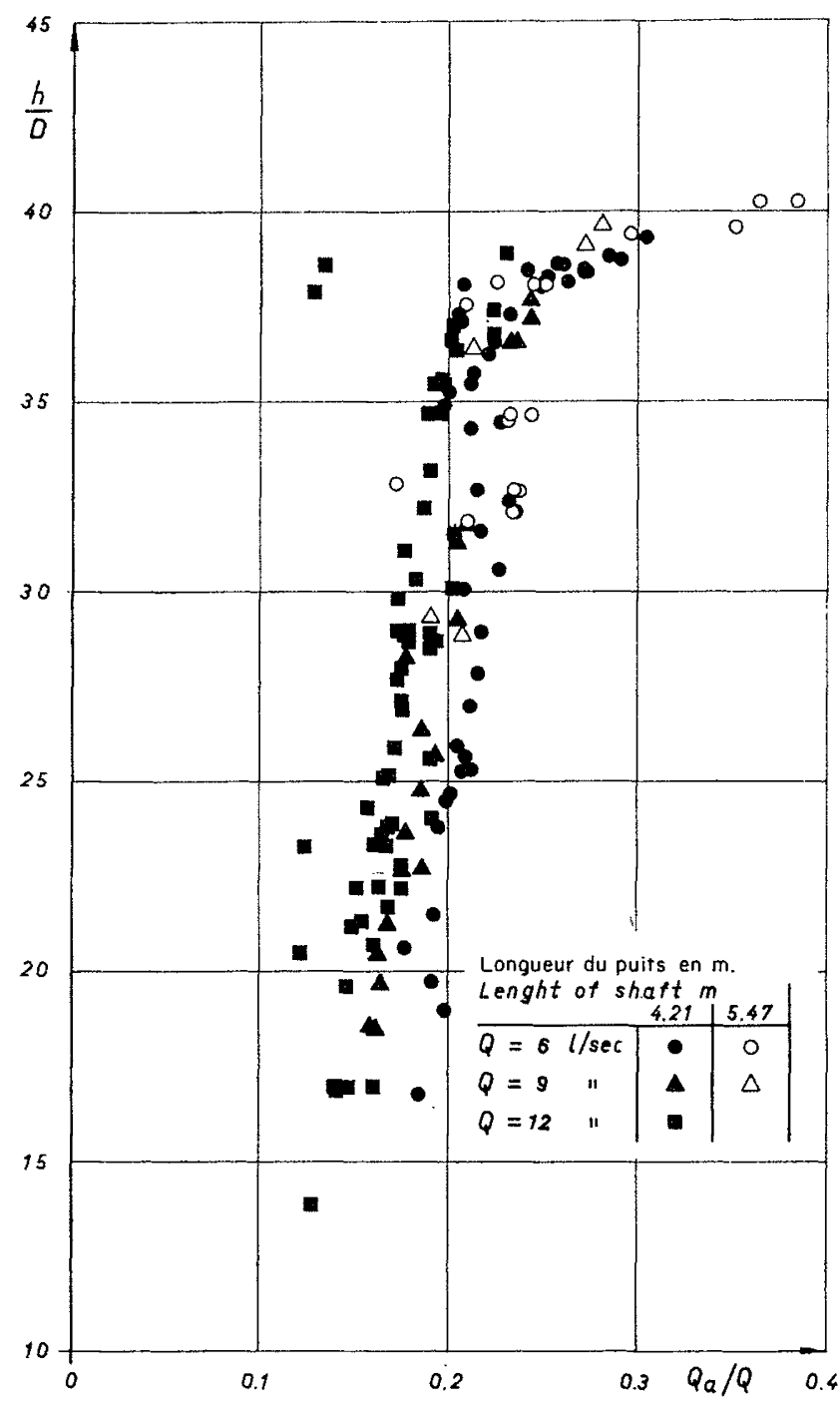

Frg. 10

Courbe $\left[Q_{a} / Q, h / D\right]$, d'après les essais réalisés à Naples. Curve $\left[Q_{\mathrm{a}} / Q, \mathrm{~h} / D\right]$, from the Naples tests.

single experiments have confirmed that $Q_{a}$ depends on $h$ according to curve (8), they have also shown up a number of reasons for the scatter among the experimental points.

Tests carried out by Mavis and Laushey have shown clearly that if the flow in the shaft inlet is radial instead of spiral, the air flow increases, whilst all other factors remain equal.

The Naples tests have shown that $Q_{a} / Q$ decreases if $Q$ increases, as can be seen in figure 10 , where the Naples results are plotted in greater detail.

They have also shown that the air discharge $\mathrm{Q}_{a}$ does not depend on the length of the air. and water column, provided the length of hydraulic jump is less than $a$.

Tests were also carried out at Naples with the 
nement d'air dépend des débits, à la fois à l'amont du ressaut et à l'aval du puits.

Certains auteurs ont attribué l'entraînement d'air dans des conduites fermées à un phénomène de pompage du ressaut, d'après quoi le fait que les débits d'air $Q_{a}$ dépendent du débit à l'amont du ressaut s'expliquerait par la différence de la quantité de mouvement du courant arrivant. Mais, puisque d'après (7) la quantité de mouvement dépend elle-même de la vitesse $V_{1}$, laquelle est quasi constante lorsque $h / D>30$, (et peut-être même quand $h / D>25$ ), les faibles différences entre les ressauts produits ne paraissent guère être compatibles avec les écarts importants des débits d'air $\mathrm{Q}_{a}$. Il se peut que le «pompage» dû au ressaut soit favorisé par le pouvoir d'entraînement d'air de l'eau en chute libre.

En conclusion, la vitesse de l'air au centre d'un puits vertical peut être censée s'approcher de celle de l'eau tombant en chute libre le long des parois, lorsque la pression à l'entrée est égale - ou presque égale - à la pression à la sortie du puits.

Les débits d'air peuvent se calculer d'après (3), lorsque l'eau occupe une grande partie de la section du puits, ou d'après (6), lorsqu'elle n'en occupe qu'une faible partie.

Lorsque la pression à la sortie est plus élevée que celle à l'entrée, l'entraînement d'air cesse subitement.

Dans ce dernier cas, la partie inférieure du puits se remplit généralement d'un mélange d'air et d'eau, dont le poids arrive presque à équilibrer la différence entre les pressions. L'entraînement d'air dépend, en premier lieu, de la hauteur de la chute libre de l'eau, et du pourcentage d'air présent dans le mélange. A condition que la longueur de la partie inférieure du puits remplie d'un mélange d'air et d'eau soit suffisamment grande, les débits d'air peuvent être évalués, d'après l'équation (8). apparatus shown in figure 11 . The values of $Q_{\mathrm{a}} / \mathrm{Q}$ obtained were higher than those obtained with the apparatus shown in figure $1, Q$ and $h$ being equal.

This implies that whenever a complete jump develops in the shaft, the air entrainment depends on the flows both upstream of jump and downstream of the shaft.

Some authors have attributed air entrainment in closed pipes to a pumping effect of the hydraulic jump, thus explaining the dependence of the air flows $Q_{a}$ on the flow upstream of the jump by the difference in the impact of the oncoming current. However, as, according to (7), the impact itself depends on the velocity $V_{1}$, which is almost constant when $h / \mathrm{D}>30$ (and perhaps even when $h / \mathrm{D}>25$ ), the small differences between the generated jumps do not appear to match the large differences between the air flows $\mathrm{Q}_{a}$. It may be that the pumping action of the jump is facilitated by the air entrainment properties of the freely falling water.

To conclude, the velocity of air in the centre of a shaft can be considered to approach that of water falling freely along the walls, when the pressure at the inlet is equal, or almost equal to that at the shaft outlet.

Air flows can be calculated from (3) or (6), depending on whether the water occupies a large portion of the shaft cross-section or a small one.

If the pressure at the outlet is greater than at the inlet, the air entrainment decreases suadenly.

In this case, the lower portion of the shaft usually fills up with a mixture of air and water, the weight of which almost balances out the pressure differences. The air entrainment chiefly depends on the height over which the water falls freely, and on the proportion of air in the mixture. If the lower part of the shaft containing an air-and-water mixture is sufficiently long, the air flows can be evaluated from (8).

\section{BIBLIOGRAPHIE BIBLIOGRAPHY}

[1] Viparelly M. : Trasporto di aria da parte di correnti idriche in condotti chiusi. L'Energia Elettrica, novembre 1954 .

[2] Kalinske A.A.: Hydraulics of vertical drain and overflow pipes. University of Iowa, Studies in Engineering, Bull. 26, pag. 26.

[3] Marquenet G. : Entraînement d'air par un écoulement en conduite verticale. Application aux puits d'adductions secondaires. Proceedings Minnesota International Hydraulics Convention, septembre 1953, pag. 489 .

[4] Laushey L. M. et Mavis F.T.: Air entrained by water flowing down vertical shafts. Proceedings Minnesota International Hydraulics Convention, Minneapolis, 1953 , pag. 483 .
[5] Viparelli M.: Su un particolare tipo d'imbocco e sull'efflusso con vortice. L'Energia Elettrica, ottobre 1950.

[6] Viparelli M. : Fast water flow in steep channels. VIIth Congress of the I.A.H.R., Lisbon, July 1957.

[7] Witrmann $H$. et Bellina W. : Ausbildung und Bemessung von Fallschächten bei Wasserkraftanlagen. Die Wasserwirtschaft, 1948-49, $\mathrm{n}^{\circ} 3$.

[8] Dawson F.M. et Kalinsie A.A. : Report on hydraulics and pneumatics of plumbing drainage systems. I. University of Iowa, Studies in Engineering, Bulletin 10. 